\title{
Selective Extraction of Sinapic Acid Derivatives from Mustard Seed Meal by Acting on pH: Toward a High Antioxidant Activity Rich Extract
}

\author{
Morad Chadni ${ }^{1, *}$, Amandine L. Flourat ${ }^{1} \mathbb{D}$, Valentin Reungoat ${ }^{1,2} \mathbb{D}$, Louis M. M. Mouterde ${ }^{1}\left(\mathbb{D}\right.$, Florent Allais ${ }^{1} \mathbb{D}$ \\ and Irina Ioannou $1, *$
}

1 URD Agro-Biotechnologies Industrielles, CEBB, AgroParisTech, 51110 Pomacle, France; amandine.flourat@agroparistech.fr (A.L.F.); valentin.reungoat@agroparistech.fr (V.R.); louis.mouterde@agroparistech.fr (L.M.M.M.); florent.allais@agroparistech.fr (F.A.)

2 Extractis, 33 Avenue Paul Claudel, 80480 Dury, France

* Correspondence: morad.chadni@agroparistech.fr (M.C.); irina.ioannou@agroparistech.fr (I.I.)

\begin{abstract}
The aim of this paper is to study the effect of the $\mathrm{pH}$ on the extraction of sinapic acid and its derivatives from mustard seed meal. Solutions of acidic $\mathrm{pH}(\mathrm{pH} 2)$, basic $\mathrm{pH}(\mathrm{pH} 12)$ and distilled water (uncontrolled $\mathrm{pH} \sim 4.5$ ) were tested at different percentages of ethanol. The maximum extraction yield for sinapic acid (13.22 $\mu \mathrm{mol} / \mathrm{g}$ of dry matter (DM)) was obtained with a buffered aqueous solution at $\mathrm{pH} 12$. For ethyl sinapate, the maximum extraction yield reached $9.81 \mu \mathrm{mol} / \mathrm{g}$ DM with $70 \%$ ethanol/buffered aqueous solution at $\mathrm{pH} 12$. The maximum extraction yield of sinapine $(15.73 \mu \mathrm{mol} / \mathrm{g} \mathrm{DM})$ was achieved with $70 \%$ ethanol/buffered aqueous solution at pH 2. The antioxidant activity of each extract was assessed by DPPH assay; the results indicated that the extracts obtained at $\mathrm{pH} 12$ and at low ethanol percentages $(<50 \%)$ exhibit a higher antioxidant activity than extracts obtained at acidic conditions. Maximum antioxidant activity was reached at $\mathrm{pH} 12$ with buffer solution (11.37 $\mathrm{mg}$ of Trolox Equivalent/g DM), which confirms that sinapic acid-rich fractions exhibit a higher antioxidant activity. Thus, to obtain rich antioxidant extracts, it is suggested to promote the presence of sinapic acid in the extracts.
\end{abstract}

Keywords: sinapic acid; sinapine; ethyl sinapate; $\mathrm{pH}$; mustard seed meal; extraction; polyphenols

Publisher's Note: MDPI stays neutral with regard to jurisdictional clai$\mathrm{ms}$ in published maps and institutional affiliations.

Copyright: (C) 2021 by the authors. Licensee MDPI, Basel, Switzerland. This article is an open access article distributed under the terms and conditions of the Creative Commons Attribution (CC BY) license (https:// creativecommons.org/licenses/by/ $4.0 /)$.

\section{Introduction}

Phenolic acids and their derivatives constitute one of the most common groups of phenolic compounds in plants. These molecules emerge as high value added products, as they play an essential role for human nutrition and health [1,2]. In recent years, sinapic acid and its derivatives such as sinapine and ethyl sinapate have attracted increasing attention thanks to their numerous biological activities. Indeed, sinapic acid has antimicrobial [3], antioxidant [4], antilipidemic [5], anti-inflammatory [6] and neuroprotective activities [7]. Moreover, sinapine has recently shown, thanks to its antioxidant activity, a protective effect against severe ischemic stress [8], and an inhibitory effect of acetylcholinesterase, beneficial for treating Alzheimer's and Parkinson's diseases $[9,10]$.

Sinapic acid and its derivatives are present in various plants, especially in Brassicaceae seeds including rapeseed (Brassica napus) and mustard (Brassica juncea and Sinapis alba). Most of these phenolic compounds remain in the meal after pressing [11]. The amount of these compounds depends on the variety of the plant, the harvest year, the cultivation region and the processing method. Khattab et al. reported contents between 6.16-22.54, 17.73-19.71 and 14.56-16.66 mg/g of total phenolics in the defatted canola seeds (18 samples), press cakes (3 samples) and meals (7 samples), respectively [12].

Recently, the safety, side effects and the manufacturing process of chemically synthesized antioxidants have been discussed [13]. Thus, a need has arisen to replace them with 
bio-based antioxidant molecules, in particular in the pharmaceutical, cosmetic and food fields [14]. Industrial and agricultural by-products could be a source of these bio-based molecules. However, their production, which often includes an extraction and purification steps, must be relatively cheap.

This paper deals with the valorization of mustard seeds meal, one of the main byproducts generated by local mustard producers in the Grand Est region of France. These by-products represent an interesting and cheap renewable material for the obtention of high added value sinapic acid derivatives, thus providing a financial support to cultivate and promote these crops in the region.

The extraction process is considered the most critical step in sample preparation [15]. This applies to extracts rich in phenolic compounds which are isolated from biomass [16]. Organic solvents and/or physical pretreatments are generally used as they improve the extraction capacity of the process [14]. Concerning the extraction of sinapic acid derivatives, the most common process is the hydro-alcoholic liquid/solid extraction, either with ethanol [17-19] or methanol [20-22]. Other studies have investigated the combination of hydro-ethanolic extraction with physical pretreatments such as ultrasound $[4,23,24]$, microwaves and high pressure accelerated solvent extraction [25].

An important aspect of the extraction of sinapic acid derivatives (SADs) is the selection of an appropriate $\mathrm{pH}$. Indeed, several studies have shown that the $\mathrm{pH}$ affects the yield, stability and antioxidant activity of phenolic extracts [26-28]. The selection of the extraction $\mathrm{pH}$ depends on the chemical structure of the phenolic compounds and their $\mathrm{pKa}$ [29].

Mustard seeds meal being commonly acid ( $\mathrm{pH} \sim 4.5$ ), adjusting the $\mathrm{pH}$ of the extraction could influence the affinity of SAD compounds with the solvent. To the best of our knowledge, the influence of $\mathrm{pH}$ on the extraction of SADs has not yet been reported. Furthermore, in this work, the quantification of SADs is based on a precise measurement by UHPLC which is not the case in other studies where SADs were estimated through the measurement of total phenols by the Folin Ciocalteu assay [17].

Thus, the objective of this paper is to study and understand the effect of the $\mathrm{pH}$ of the extraction medium on the recovery of SADs from mustard seed meal. For this, the main SADs obtained from different extraction conditions will be identified by UHPLC. Then, the contents of the three main derivatives of sinapic acid (i.e., sinapine, ethyl sinapate and sinapic acid), and the antioxidant activity of the extracts will be measured for three $\mathrm{pH}(2,4.5,12)$ at different percentages of ethanol $(0 \%, 30 \%, 50 \%$ and $70 \%)$. For basic $\mathrm{pH}$ solutions, the influence of three different alkaline agents used to reach $\mathrm{pH} 12$ on the yield of extraction, the selectivity of extraction and the antioxidant activity was compared.

\section{Results and Discussion}

Different operating conditions of the extraction process were tested for the extraction of SADs from mustard seed meal. The effects of the $\mathrm{pH}$, the percentage of ethanol and the type of base used for the basification of the medium were determined. For this, the comparison of the UHPLC profiles, the determination of the SAD contents and the measurement of the antioxidant activity of the extracts were performed.

\subsection{Comparison of the HPLC Profiles Under Different Operating Conditions}

The SADs extracted were identified by UHPLC analysis under different extraction conditions ( $\mathrm{pH}$, ethanol percentage). The chromatograms obtained are presented Figure 1. 

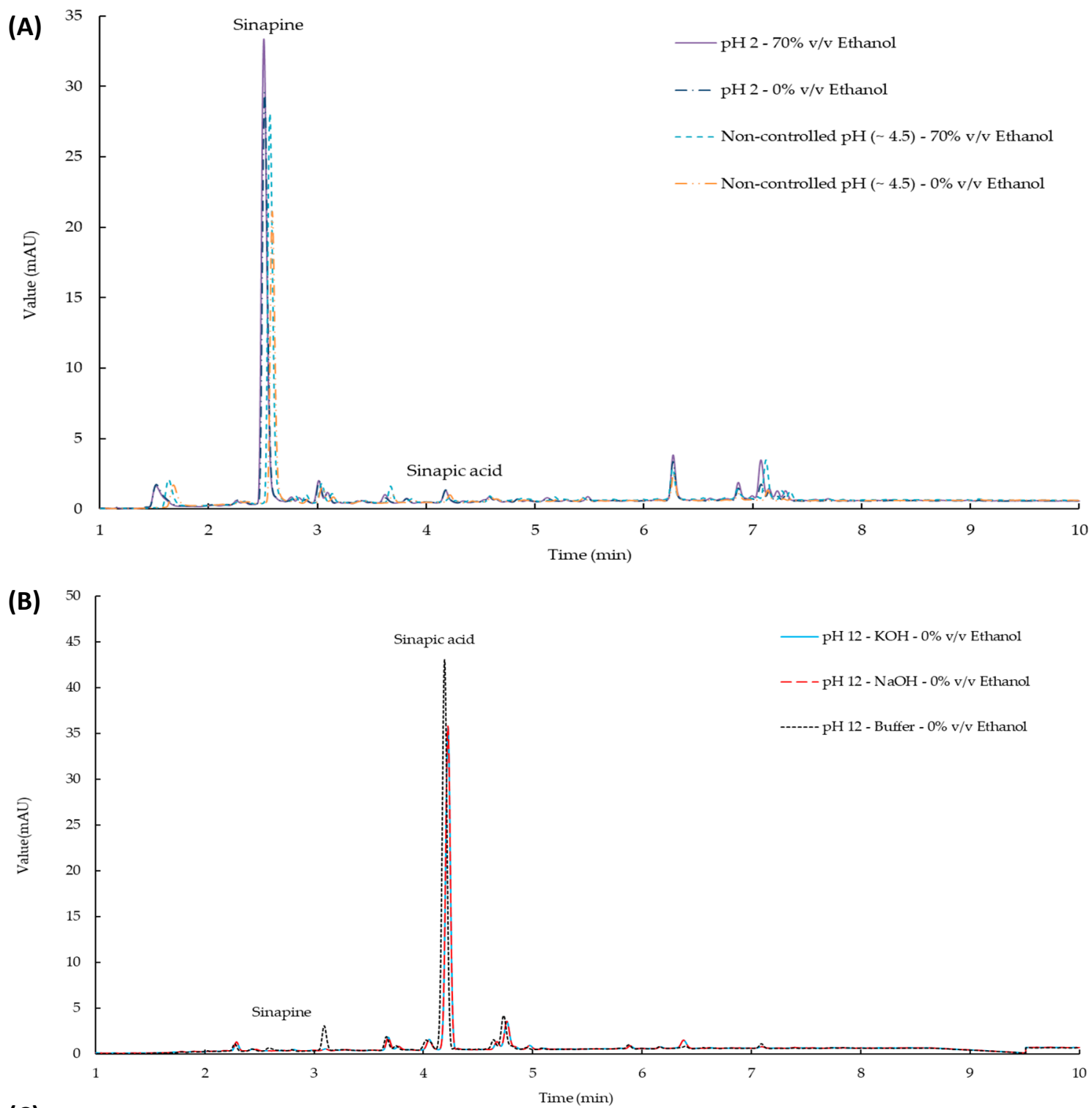

(C)

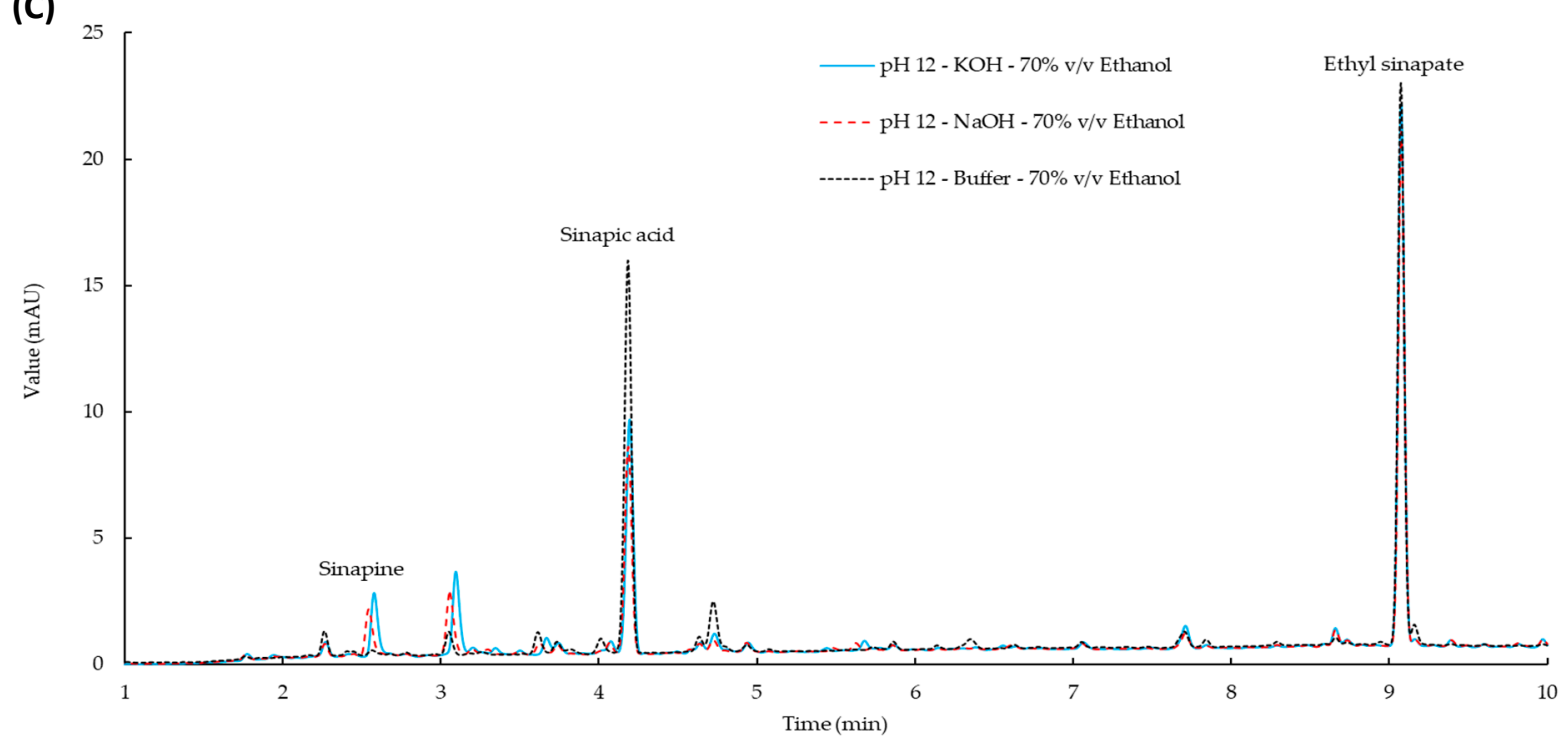

Figure 1. HPLC chromatograms of extracted sinapic acid derivatives (SAD) at acidic $\mathrm{pH}$ at $0 \%$ and $70 \%$ ethanol (A), basic $\mathrm{pH}$ at $0 \%(\mathbf{B})$ and basic $\mathrm{pH}$ at $70 \%$ ethanol (C). 
Figure 1A shows the chromatograms of the extracts obtained under acidic conditions (uncontrolled $(\mathrm{pH} \sim 4.5)$ and $\mathrm{pH} 2$ ) with $0 \%$ and $70 \% v / v$ ethanol. Sinapine is the main SAD that appears with a retention time of $2.5 \mathrm{~min}$ whereas sinapic acid is present in very low concentrations at $4.2 \mathrm{~min}$. This result can be explained by the fact that, under these extraction conditions, sinapine is not hydrolyzed [30]. Thus, the amount of free sinapic acid that can be extracted from mustard seed meals is negligible as shown Figure 1A. Similar results were obtained by Dubie [4] during an aqueous extraction at a temperature of $80^{\circ} \mathrm{C}$ from mustard seeds meal. The presence of ethanol in the extraction solvent increases the intensity of the sinapine peak, at acidic $\mathrm{pH}$, without changing the selectivity of the extraction process.

The chromatograms of the extracts carried out at basic $\mathrm{pH}$ are shown in Figure 1B for an aqueous extraction $(0 \% v / v$ ethanol) and in Figure $1 \mathrm{C}$ for a $70 \% v / v$ ethanol solvent. At basic $\mathrm{pH}$, sinapine is present at very low concentrations, while the main SAD is sinapic acid for aqueous extraction (Figure 1B). This observation is consistent with previous results. Indeed, the formation of sinapic acid through the hydrolysis of sinapine is a very wellknown reaction which occurs at basic $\mathrm{pH}$ or in presence of specific enzymes [31].

In the case of the hydro-alcoholic extraction $(70 \% v / v$ ethanol) at basic $\mathrm{pH}$, the most intense peak corresponds to ethyl sinapate with a retention time of $9.1 \mathrm{~min}$. While ethyl sinapate can be formed through the esterification of sinapic acid in the presence of ethanol under acidic conditions, its production during the extraction process from mustard seeds meal in basic medium proceeds directly through the transesterification of sinapine by ethanol as shown in Scheme 1.

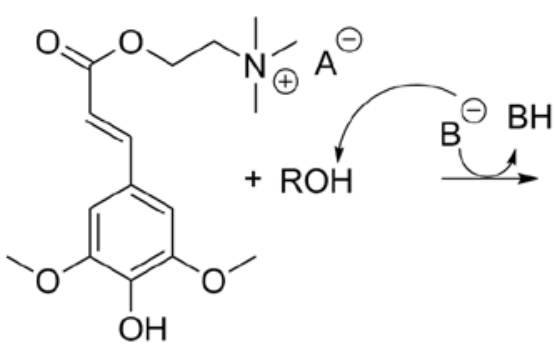

Sinapine
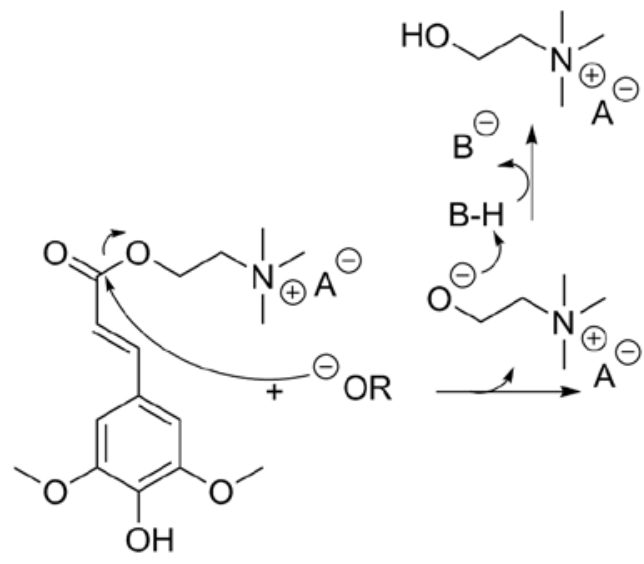<smiles>[R]OC(=O)/C=C/c1cc(OC)c(O)c(OC)c1</smiles>

$\mathrm{R}=\mathrm{H}$, Sinapic acid

Scheme 1. Reaction formation of sinapic acid and ethyl sinapate.

Moreover, an effect of the nature of the base on the intensity of the peaks is observed (Figure 1C). Indeed, when a buffer is used, an increase in the intensity of the sinapic acid peak is observed, whereas that of ethyl sinapate remains unchanged. Thus, the selectivity of the extraction process is improved by using a $\mathrm{pH} 12$ aqueous (bis)carbonate buffer over $\mathrm{KOH}$ and $\mathrm{NaOH}$ solutions.

\subsection{Comparison of the SAD Contents Under Different Operating Conditions}

The comparison of the UHPLC profiles made it possible to show the selectivity of the extraction process on the SADs as a function of the $\mathrm{pH}$ and the percentage of ethanol. In order to quantify the effect of these two parameters, the contents of sinapine, sinapic acid and ethyl sinapate, as well as the antioxidant activity of the extracts, were determined. 


\subsubsection{Evolution of the Contents of SAD at Acidic $\mathrm{pH}$}

As shown in Section 2.1, sinapine is the only SAD extracted at $\mathrm{pH} 2$ and uncontrolled $\mathrm{pH}$. The comparison of the sinapine contents obtained at $\mathrm{pH} 2$ and at an uncontrolled $\mathrm{pH}$ for different percentages of ethanol is presented in Figure 2.

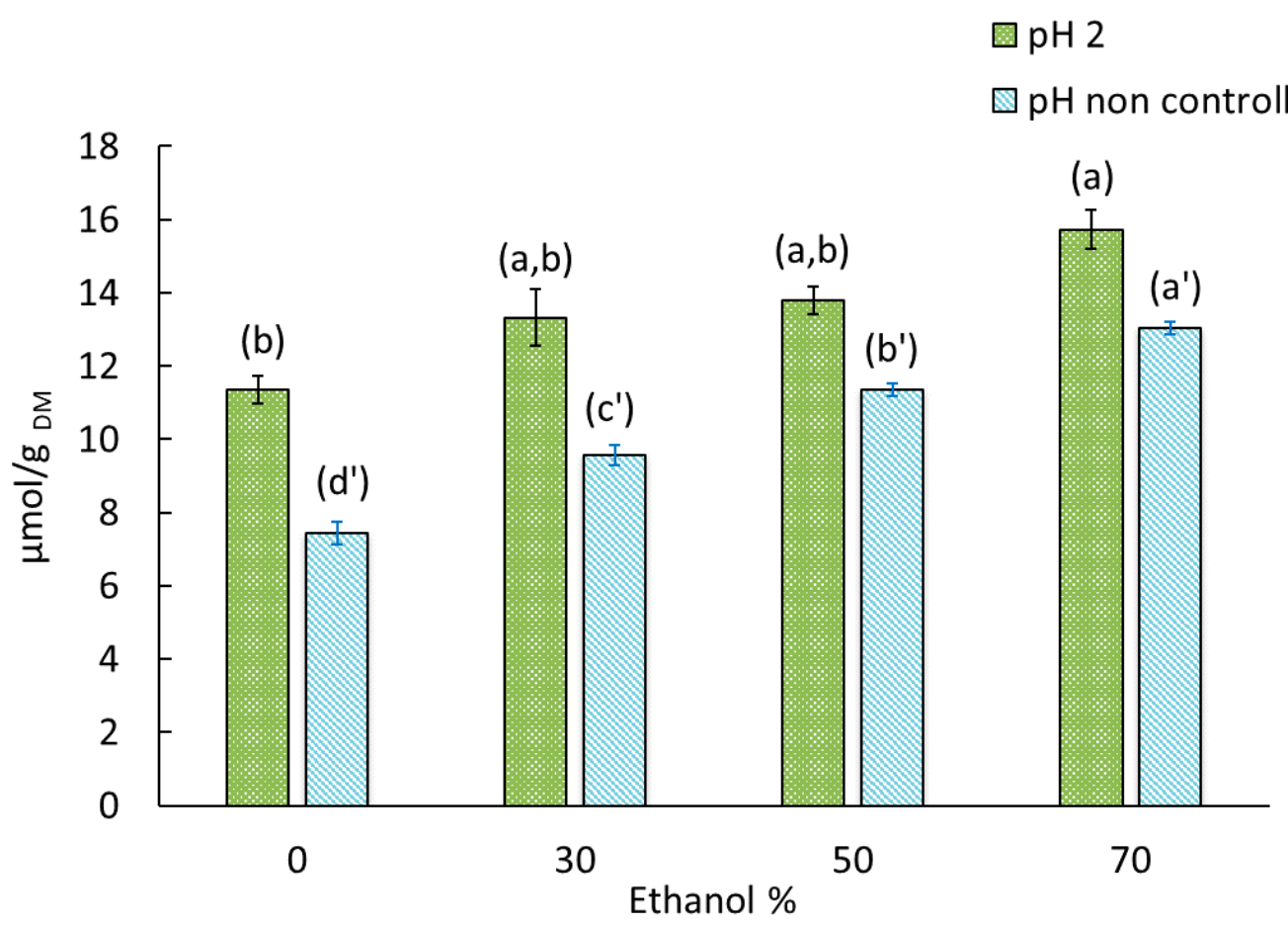

Figure 2. Evolution of the sinapine content from mustard seed meal at $\mathrm{pH} 2$ and at non-controlled $\mathrm{pH}$. Bars with the same letter are not significantly different $(p<0.05)$ according to Tukey's test at the $95 \%$.

Extraction at $\mathrm{pH} 2$ leads to higher yields of sinapine compared to the extraction at uncontrolled $\mathrm{pH}$. The difference between these two conditions is particularly high for a low percentage of ethanol. Indeed, for an aqueous extraction $(0 \% v / v$ ethanol), sinapine content increases by $52.5 \%$ between the two conditions, while the increase is only $20.7 \%$ for an extraction with $70 \% v / v$ ethanol. The highest yields of sinapine obtained are 15.73 and $13.03 \mu \mathrm{mol} / \mathrm{g} \mathrm{DM}$. They correspond to an extraction with $70 \% v / v$ ethanol at $\mathrm{pH} 2$ and at uncontrolled $\mathrm{pH}$, respectively. This is in agreement with the results of Reungoat [18] who found that the use of $70 \% v / v$ ethanol is the most efficient rate for sinapine extraction. Increasing the acidity of the extraction medium thus promotes the extraction of sinapine. This could be due to the denaturation of the cell membranes of the seeds, thus releasing the retained phenolic compounds. The same observation has been reported during the extraction of grape skin pomace under acidic conditions [32]. These results are in accordance with other researchers who reported $4.74 \pm 0.28 \mathrm{mg} / \mathrm{g}_{\mathrm{DM}}$, which is equivalent to $15.27 \mu \mathrm{mol} / \mathrm{g}$ DM of sinapine [24], and $4-10 \mathrm{mg} / \mathrm{g}$ DM of SAD with over $90 \%$ of sinapine in mustard seed meal [30].

\subsubsection{Evolution of the Contents of $\mathrm{SAD}$ at $\mathrm{pH} 12$}

Figure 3 presents the evolution of the sinapic acid (Figure 3A) and the ethyl sinapate (Figure $3 \mathrm{~B}$ ) contents for extraction at $\mathrm{pH} 12$ with different percentages of ethanol and 3 alkaline agents. 
(A)

$\square$ Ethanol 0\%

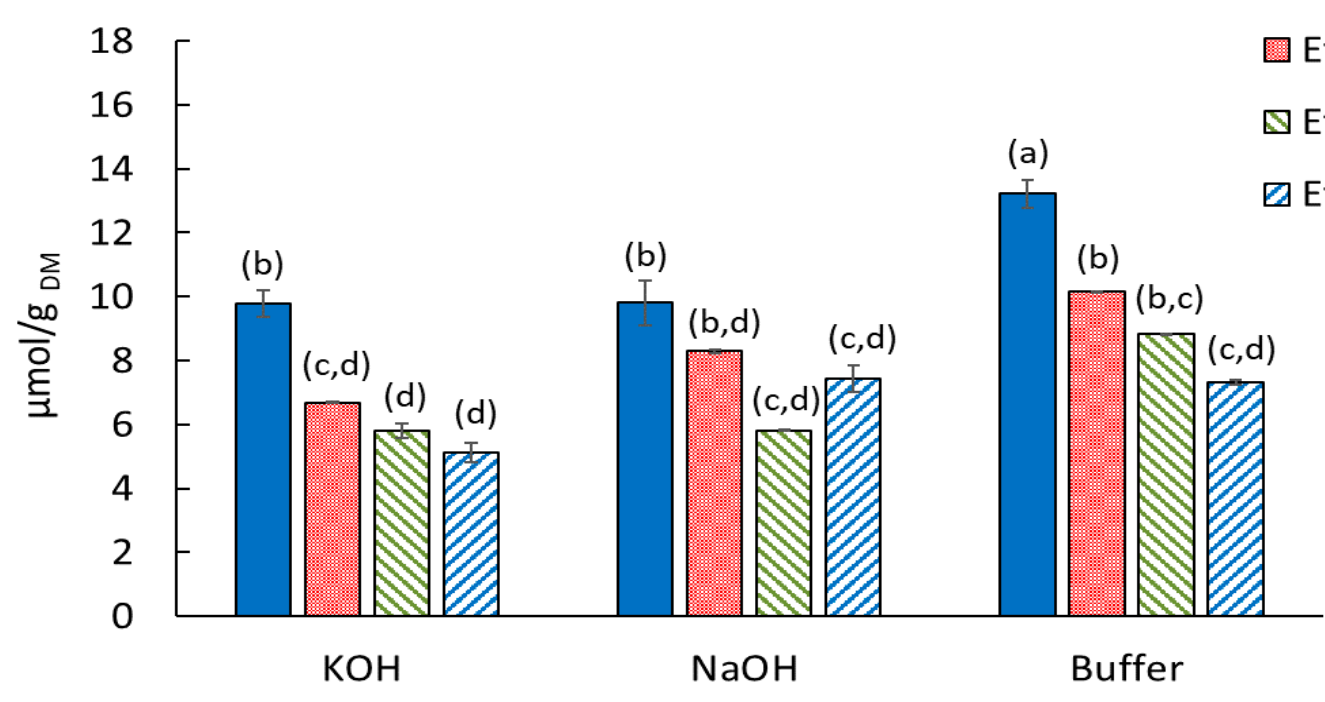

(B)

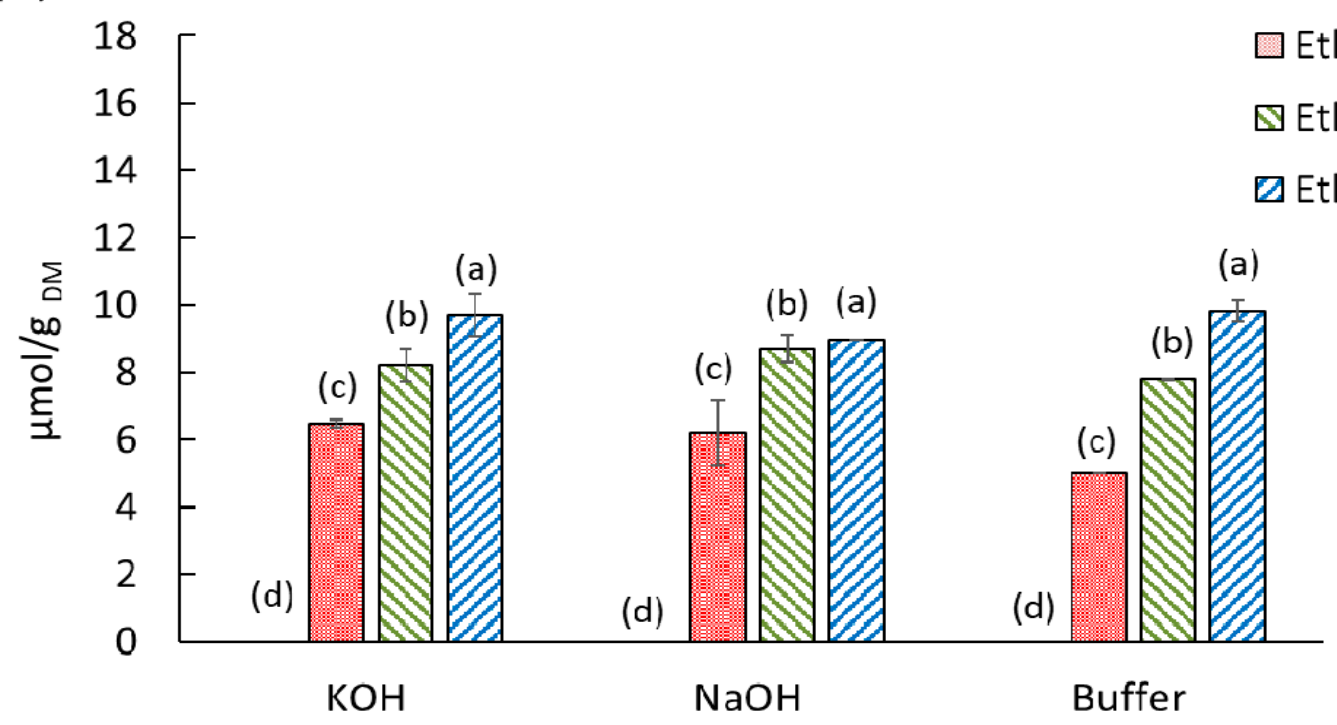

Figure 3. Sinapic acid (A) and ethyl sinapate (B) contents of extracts obtained at $\mathrm{pH} 12$ and for different percentage of ethanol. Bars with the same letter are not significantly different $(p<0.05)$ according to Tukey's test at the $95 \%$.

As shown in Figure 3, and as expected, the percentage of ethanol significantly $(p<0.05)$ affects the formation of sinapic acid and ethyl sinapate. The content of sinapic acid extracted is inversely correlated with the percentage of ethanol in the solvent. The sinapic acid content goes from $9.79 \pm 0.03,9.81 \pm 0.69$ and $13.22 \pm 0.44$ for an aqueous extraction to $5.13 \pm 0.31$, $7.43 \pm 0.42$ and $7.31 \pm 0.06 \mu \mathrm{mol} / \mathrm{g}$ DM with $70 \% v / v$ ethanol for the bases $\mathrm{KOH}, \mathrm{NaOH}$ and buffer, respectively (Figure $3 \mathrm{~A}$ ).

Figure 3A shows that the difference in yield of sinapic acid between a basified extraction with $\mathrm{KOH}$ and $\mathrm{NaOH}$ is not significant $(p>0.05)$. Concerning the buffer, no significant difference in yield exists with the previous two except for $0 \% v / v$ ethanol where the maximum yield of sinapic acid was obtained (13.22 $\pm 0.44 \mu \mathrm{mol} / \mathrm{g} \mathrm{DM})$.

According to Figure $3 \mathrm{~B}$, the nature of the base does not affect the formation of ethyl sinapate. At $0 \% v / v$ ethanol, ethyl sinapate cannot be formed and by consequence was not detected. The amount of ethyl sinapate formed is only influenced by the percentage of ethanol in the extraction solvent. At 30\%,50\% and 70\% v/v ethanol, the yield in ethyl sinapate was $5.89 \pm 0.59,8.23 \pm 0.31$ and $9.49 \pm 0.35 \mu \mathrm{mol} / \mathrm{g} \mathrm{DM}$, respectively. 
According to our results, aqueous extraction at alkaline $\mathrm{pH}$ gives significantly higher yields of total SADs than at acidic $\mathrm{pH}$. The following classification could be established for an aqueous extraction of SADs: buffer $\mathrm{pH} 12>\mathrm{pH} 12 \mathrm{NaOH} \approx \mathrm{pH} 12 \mathrm{KOH} \approx \mathrm{pH}$ $2>$ uncontrolled $\mathrm{pH}$. The same classification can be made for an extraction at $70 \% \mathrm{v} / \mathrm{v}$ ethanol with an increase in SADs yield of 30\%, 68\%, 52\%, 33\% and 73\%, respectively. Thus, one can conclude that increasing the percentage of ethanol had a significant effect on the total recovery of SADs. These results are in agreement with those reported by [4] who found that an extraction carried out with $70 \% v / v$ ethanol gives better yield of sinapic acid. This increase resulting from the addition of ethanol can be attributed to the change in the solubility, density or dielectric constant of the extraction solvent [33]. Moreover, the addition of ethanol could also accelerate the mass transfer between the liquid and the plant matrix by increasing the permeability of plant cell walls and help to break the bonds between solutes and the plant matrix [34].

\subsection{Antioxidant Activity}

Several works have shown that SADs can be used as antioxidant molecules for different applications $[3,35,36]$. Figure 4 shows the antioxidant activity of the various extracts, measured by the DPPH radical scavenging method, expressed in mg of Trolox equivalent per $100 \mathrm{~g}$ DM. The SADs composition of the studied extracts is presented in the supplementary data section (Table S1).

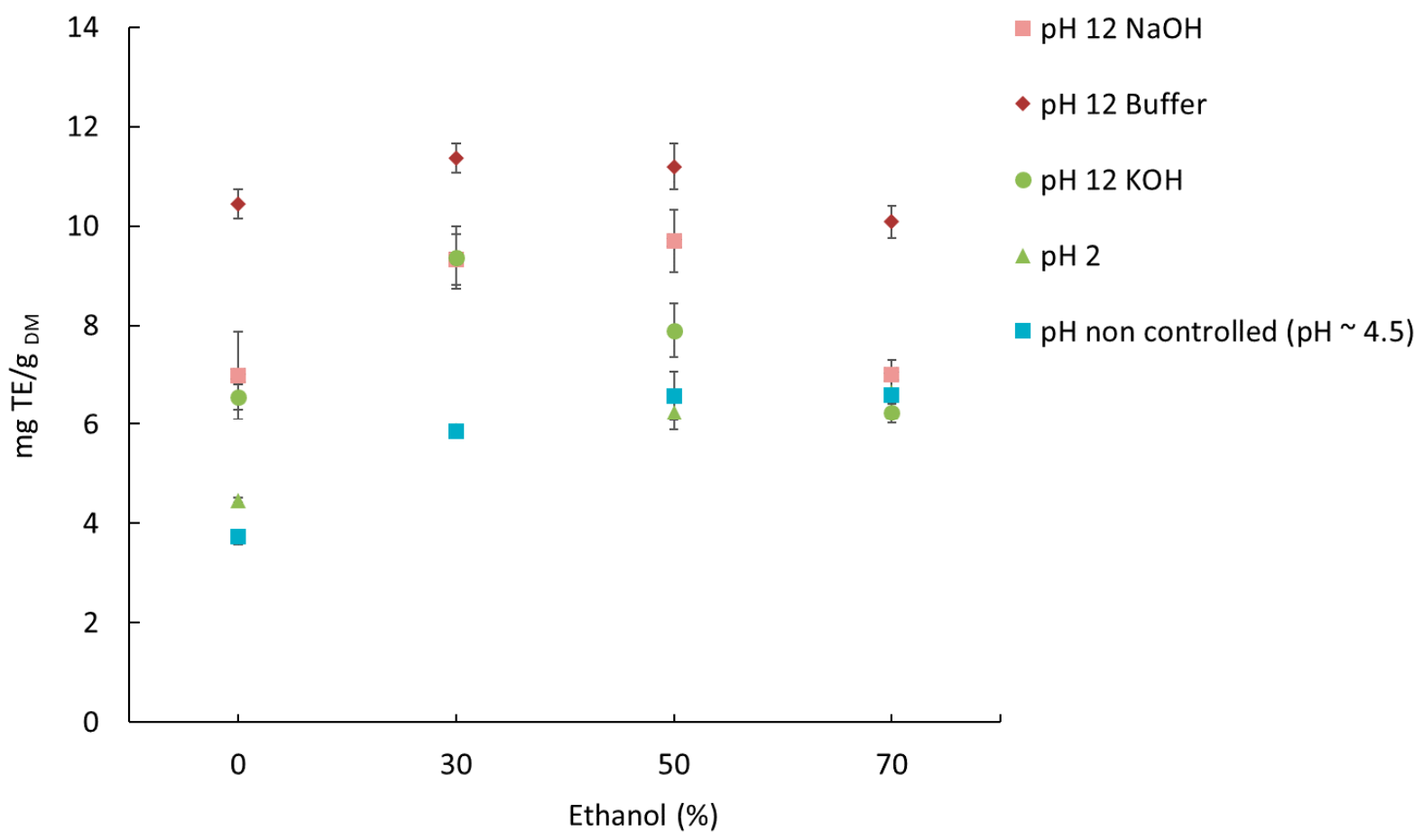

Figure 4. Antioxidant activity of extracts obtained at different operating conditions.

According to Figure 4, the most antioxidant extracts are obtained at $\mathrm{pH} 12$ with a buffer solution whatever the percentage of ethanol $(p>0.05)$. The antioxidant activity is $10.77 \pm 0.5 \mathrm{~g} \mathrm{TE} / \mathrm{g}_{\mathrm{DM}}$. The least antioxidant extracts are obtained for an acidic $\mathrm{pH}$. This is explained by the presence of different SADs in the extracts. Indeed, at acidic $\mathrm{pH}$, only sinapine is present in the medium, while at basic $\mathrm{pH}$, the formation of sinapic acid occurs. This can be explained by a weaker antioxidant activity of sinapine $\left(\mathrm{IC}_{50}=165.7 \pm 0.9 \mu \mathrm{M}\right)$ than that of sinapic acid $\left(\mathrm{IC}_{50}=32.4 \pm 2.2 \mu \mathrm{M}\right)$ [37]. However, when ethyl sinapate is formed, a decrease in antioxidant activity is observed. This is the case for an extraction at $70 \% v / v$ ethanol, where all the antioxidant activities are equivalent except at $\mathrm{pH} 12$ 
with a buffer solution. This can also be explained by the values of antioxidant activity. Indeed, ethyl sinapate has an $\mathrm{IC}_{50}$ of $51.9 \pm 6.3 \mu \mathrm{M}$, whereas sinapic acid has an $\mathrm{IC}_{50}$ of $32.2 \pm 6.2 \mu \mathrm{M}$ [38]. Thus, to obtain the most antioxidant extracts from mustard seeds meal, it is necessary to promote the presence of sinapic acid in the extracts.

\section{Material and Methods}

\subsection{Chemicals and Materials}

Sodium hydroxide $(97 \%)$, potassium hydroxide $(85.3 \%)$, sodium bicarbonate $(>99 \%)$, sodium carbonate (>99\%), glacial acetic acid (99\%), DPPH (2,2-Diphenyl-picrylhydrazyl) $(>97.0 \%)$ and Trolox ${ }^{\circledR}$ (6-hydroxy-2,5,7,8-tetramethylchromane-2-carboxylic acid)) $(>98.0 \%)$ were obtained from VWR, Fontenay-sous-Bois, France. Acetonitrile (99.9\%), formic acid $(98-100 \%)$ and methanol (99.9\%) were purchased from Thermo Fisher, Illkirch France.

Mustard seed meal (Brassica juncea) consisting of seed hulls, residual cotyledons and other minor seed fractions was used as the raw material. The mustard seed meal was obtained as by-product of the mechanical cold pressing of cured mustard seeds and was provided by Charbonneaux-Brabant (Reims, France) and stored in the dark at $4{ }^{\circ} \mathrm{C}$ until extraction.

\subsection{Extraction Process}

Extraction of SADs from mustard seed meal was performed in a $250 \mathrm{~mL}$ tricol flask with a condensing column. The solvent used is water at different $\mathrm{pH}$ and absolute ethanol at different percentages ( $V_{\text {Ethanol }} / V_{\text {Water }}$ ), the liquid-to-solid ratio was fixed at $10 \mathrm{~mL} / \mathrm{g}$ of seed meal. The temperature of extraction was fixed during the extraction at $70{ }^{\circ} \mathrm{C}$ in order to avoid the evaporation of ethanol and to provide better extraction yield as shown in our previous papers where temperatures between 70 and $75{ }^{\circ} \mathrm{C}$ were found to be better for the extraction of sinapic acid derivatives $[17,18]$. Time of extraction was optimized at $0 \%$ ethanol in non-controlled $\mathrm{pH}$ solution, it was found that the extraction kinetic was stable after $2 \mathrm{~h}$, then the time of extraction was fixed at this duration.

The different experiments performed to study the effect of the $\mathrm{pH}$ on the extraction process are gathered in Table 1.

Carbonate-bicarbonate buffer $(0.1 \mathrm{M})$ was prepared at $\mathrm{pH} 10.6$ from sodium bicarbonate and sodium carbonate and adjusted to $\mathrm{pH} 12$ by a solution of $1 \mathrm{M} \mathrm{NaOH}$. Basic solutions of $\mathrm{NaOH}$ and $\mathrm{KOH}$ were prepared by adjusting the $\mathrm{pH}$ of distilled water with $1 \mathrm{M}$ solutions of sodium hydroxide and potassium hydroxide, respectively. Acidic solution was prepared by adjusting the $\mathrm{pH}$ to 2 by adding glacial acetic acid (99\%) to distilled water. For uncontrolled $\mathrm{pH}$, the mustard seed meal was used as received from the company without any modification, the value of $\mathrm{pH}$ at $10 \mathrm{~g} / \mathrm{mL}$ in distilled water was 4.5 .

The liquid extract was separated from the solid residue by centrifugation (Allegra X15-R, Beckman Coulter, Villepinte, France) at $4713 \mathrm{~g}$ for 20 min at $4{ }^{\circ} \mathrm{C}$.

The extract obtained from mustard seeds meal was filtered through a $0.20 \mu \mathrm{m}$, Chromatofil filter, Xtra RC-20/25, with a 1-mL syringe. Sinapine, sinapic acid and ethyl sinapate were quantified by reversed-phase UHPLC-DAD (Ultimate 3000; Dionex, ThermoFisher, Illkirch, France) equipped with a quaternary pump, auto sampler, column furnace and diode array detector. A gradient elution was performed using water (solvent A), acetonitrile (solvent B) and formic acid $0.1 \%$ (solvent C) on a C18 Thermo Scientific ${ }^{\mathrm{TM}}$ Accucore $^{\mathrm{TM}}$ aQ; $100 \times 3 \mathrm{~mm}$ with $2.6 \mu \mathrm{m}$ particle size. Initial solvent was $45 \% \mathrm{~A}, 5 \% \mathrm{~B}$ and $50 \% \mathrm{C}$. Solvent B gradient followed: $5 \%$ (0 min), 10\% (0.990 min), 15\% (3.190 $\mathrm{min}), 30 \%$ (7.440 min), $5 \%$ (8.510 min), while $\mathrm{C}$ remained constant. The column was maintained at $48{ }^{\circ} \mathrm{C}$ and run at a constant flow rate of $0.8 \mathrm{~mL} / \mathrm{min}$. Total run time was 13 min with a $20 \mu \mathrm{L}$ injection volume, and the detection wavelength was $320 \mathrm{~nm}$. Sinapine chloride and ethyl sinapate standards were synthesized in-house and used to establish calibration curves [3]. Sinapic acid standard ( $\geq 98 \%$ ) was purchased from Sigma-Aldrich, Saint-Quentin-Fallavier, France. NMR spectrum of sinapine and ethyl sinapate are presented in the supplementary material section. 
Table 1. The different operating conditions tested for the extraction of SADs.

\begin{tabular}{|c|c|c|c|c|c|}
\hline & pH Medium & pH Value & Time (h) & $\begin{array}{c}\text { Temperature } \\
\left({ }^{\circ} \mathrm{C}\right)\end{array}$ & $\begin{array}{c}\text { Ethanol } \\
(v / v \%)\end{array}$ \\
\hline \multirow{4}{*}{\multicolumn{2}{|c|}{ Acid }} & \multirow{4}{*}{2} & \multirow{4}{*}{2} & \multirow{4}{*}{70} & 0 \\
\hline & & & & & 30 \\
\hline & & & & & 50 \\
\hline & & & & & 70 \\
\hline \multirow{4}{*}{\multicolumn{2}{|c|}{$\begin{array}{c}\text { Sodium Carbonate- } \\
\text { bicarbonate } \\
\left(\mathrm{NaHCO}_{3} / \mathrm{Na}_{2} \mathrm{CO}_{3}\right) \\
\text { buffer }\end{array}$}} & \multirow{4}{*}{12} & \multirow{4}{*}{2} & \multirow{4}{*}{70} & 0 \\
\hline & & & & & 30 \\
\hline & & & & & 50 \\
\hline & & & & & 70 \\
\hline \multirow{8}{*}{ Base } & \multirow{4}{*}{$\mathrm{NaOH}$} & \multirow{4}{*}{12} & \multirow{4}{*}{2} & \multirow{4}{*}{70} & 0 \\
\hline & & & & & 30 \\
\hline & & & & & 50 \\
\hline & & & & & 70 \\
\hline & \multirow{4}{*}{$\mathrm{KOH}$} & \multirow{4}{*}{12} & \multirow{4}{*}{2} & \multirow{4}{*}{70} & 0 \\
\hline & & & & & 30 \\
\hline & & & & & 50 \\
\hline & & & & & 70 \\
\hline \multirow{4}{*}{\multicolumn{2}{|c|}{$\begin{array}{c}\text { Uncontrolled } \\
\text { ( } \mathrm{pH} \text { of the mustard seed meal) }\end{array}$}} & \multirow{4}{*}{$\sim 4.5$} & \multirow{4}{*}{2} & \multirow{4}{*}{70} & 0 \\
\hline & & & & & 30 \\
\hline & & & & & 50 \\
\hline & & & & & 70 \\
\hline
\end{tabular}

\subsection{Ultra High-Performance Liquid Chromatography (UHPLC) Analyses}

\subsection{Antioxidant Activity Assay}

The radical scavenging activity was determined using a solution of 2,2-Diphenylpicrylhydrazyl (DPPH•) at $0.06 \mathrm{mM}$. The antioxidant capacity of a given molecule was measured against a standard, Trolox (6-hydroxy-2,5,7,8-tetramethyl-chroman-2-carboxylic acid). The scavenging capacity was determined by monitoring the decrease in absorbance at $515 \mathrm{~nm}$ (maximum absorbance of DPPH•), which disappeared upon reduction by an antiradical compound. Spectrophotometric analyses were carried out as described by Brand-Williams [39]. For the determination of the radical scavenging activity, $1450 \mu \mathrm{L}$ of DPPH• colored radical $(0.06 \mathrm{mM}$ in $96 \%$ methanol) was added to $50 \mu \mathrm{L}$ of a suitable dilution of sample extract or Trolox (standard) in methanol solution. The mixture was stirred and then incubated in the absence of light at room temperature for $1 \mathrm{~h}$. Absorbance was measured at the wavelength of $515 \mathrm{~nm}$ [39]. The percentage of DPPH• inhibition was calculated using Equation (1):

$$
\text { Inhibition }(\%)=\frac{A_{\text {Control }}-A_{\text {Sample }}}{A_{\text {Control }}} \times 100
$$

where $A_{\text {Control }}$ is the absorbance of the control at $515 \mathrm{~nm}$, and $A_{\text {Sample }}$ is the absorbance of the sample at $515 \mathrm{~nm}$.

Methanolic solutions of Trolox at $0.05(0.0125 \mathrm{mg} / \mathrm{mL})$ to $1 \mathrm{mM}(0.25 \mathrm{mg} / \mathrm{mL})$ were used for calibration. The radical scavenging activity was expressed as $\mathrm{mg}$ of Trolox Equivalent (TE) per $100 \mathrm{~g}$ of dry matter (mg TE/100 g DM). 


\subsection{Statistical Analysis}

All experiments were conducted at least in duplicates. The error bars indicated on the figures represent the standard deviations. Significant effects of $\mathrm{pH}$ and ethanol percentages were determined by an ANOVA $(p<0.05)$, and a Tukey test was carried out to find significative differences between groups. Statistical analysis was performed under R [40].

\section{Conclusions}

This study highlights the importance of controlling the operating conditions of the extraction process for the recovery of SADs from mustard seed meal. Indeed, it has been shown that at acidic $\mathrm{pH}$, the main SAD is sinapine, while at basic $\mathrm{pH}$, in the absence of ethanol, sinapic acid is mainly present. Moreover, in the presence of ethanol, at basic $\mathrm{pH}$, a sinapic acid/ethyl sinapate mixture is obtained. The ethyl sinapate content is also maximum at $\mathrm{pH} 12$ with a $70 \% v / v$ ethanol/buffer solution.

The use of SADs from mustard seed meal as a natural antioxidant will boost the substitution of synthetic antioxidants by natural antioxidants, since synthetic antioxidants have been shown to have negative health effects, such as lipid, enzyme and pathological alterations. In this work, it was found that extraction at basic $\mathrm{pH}$ with a buffer solution maximizes the antioxidant activity of the extract by increasing the selectivity of the extraction process for sinapic acid. Extracts with high ethyl sinapate content have shown slightly lower antioxidant activity than sinapic acid rich extract and higher than sinapine rich extracts. Ethyl sinapate rich extracts could be more advantageous for antioxidants intended to function in hydrophobic media such as membrane cells.

In a concept of valorization of mustard seed meal, techno-economic calculations will have to be made in order to determine the economic viability of such a process. Testing extraction at non-controlled $\mathrm{pH}$ was important in order to evaluate the effectiveness of extraction from crude seed meal without any previous modification of $\mathrm{pH}$, which will reduce the cost and the environmental impact of the industrial process. Typically, small pilot-plant scale experiments need to be performed for validation and further optimization of the process conditions.

Supplementary Materials: The following are available online, Table S1: SADs composition of the studied extracts; Figure S1: ${ }^{1} \mathrm{H}-\mathrm{NMR}$ spectrum of sinapine; Figure S2: ${ }^{13} \mathrm{C}-\mathrm{NMR}$ spectrum of sinapine; Figure S3: ${ }^{1} \mathrm{H}-\mathrm{NMR}$ spectrum of ethyl sinapate; Figure S4: ${ }^{13} \mathrm{C}-\mathrm{NMR}$ spectrum of ethyl sinapate.

Author Contributions: Conceptualization, M.C. and A.L.F.; methodology, M.C., L.M.M.M. and V.R.; validation, M.C.; A.L.F. and I.I.; investigation, M.C., A.L.F. and I.I.; data curation, M.C. and I.I.; writing—original draft preparation, M.C.; writing—review and editing, A.L.F., I.I. and F.A.; supervision, I.I., and F.A. All authors have read and agreed to the published version of the manuscript.

Funding: This research was funded by the Region Grand Est, the Conseil Départemental de la Marne and the Grand Reims.

Data Availability Statement: Data is contained within the article or supplementary material. The data presented in this study are available in this manuscript.

Acknowledgments: The authors gratefully acknowledge the financial support of the Region Grand Est, the Conseil Départemental de la Marne and the Grand Reims, as well as Charbonneaux Brabant for providing the mustard seed meal.

Conflicts of Interest: The authors declare no conflict of interest.

\section{References}

1. Cory, H.; Passarelli, S.; Szeto, J.; Tamez, M.; Mattei, J. The Role of Polyphenols in Human Health and Food Systems: A Mini-Review. Front. Nutr. 2018, 5. [CrossRef] [PubMed]

2. Ranilla, L.G.; Kwon, Y.-I.; Apostolidis, E.; Shetty, K. Phenolic compounds, antioxidant activity and in vitro inhibitory potential against key enzymes relevant for hyperglycemia and hypertension of commonly used medicinal plants, herbs and spices in Latin America. Bioresour. Technol. 2010, 101, 4676-4689. [CrossRef] [PubMed]

3. Mouterde, L.M.M.; Peru, A.A.M.; Mention, M.M.; Brunissen, F.; Allais, F. Sustainable Straightforward Synthesis and Evaluation of the Antioxidant and Antimicrobial Activity of Sinapine and Analogues. J. Agric. Food Chem. 2020. [CrossRef] [PubMed] 
4. Dubie, J.; Stancik, A.; Morra, M.; Nindo, C. Antioxidant Extraction from Mustard (Brassica juncea) Seed Meal Using High-Intensity Ultrasound. J. Food Sci. 2013, 78, E542-E548. [CrossRef] [PubMed]

5. Roy, S.J.; Mainzen Prince, P.S. Protective effects of sinapic acid on cardiac hypertrophy, dyslipidaemia and altered electrocardiogram in isoproterenol-induced myocardial infarcted rats. Eur. J. Pharmacol. 2013, 699, 213-218. [CrossRef]

6. Li, X.; Lin, J.; Ding, X.; Xuan, J.; Hu, Z.; Wu, D.; Zhu, X.; Feng, Z.; Ni, W.; Wu, A. The protective effect of sinapic acid in osteoarthritis: In vitro and in vivo studies. J. Cell. Mol. Med. 2019, 23, 1940-1950. [CrossRef]

7. Zare, K.; Eidi, A.; Roghani, M.; Rohani, A.H. The neuroprotective potential of sinapic acid in the 6-hydroxydopamine-induced hemi-parkinsonian rat. Metab. Brain Dis. 2015, 30, 205-213. [CrossRef]

8. Boulghobra, D.; Grillet, P.-E.; Laguerre, M.; Tenon, M.; Fauconnier, J.; Fança-Berthon, P.; Reboul, C.; Cazorla, O. Sinapine, but not sinapic acid, counteracts mitochondrial oxidative stress in cardiomyocytes. Redox Biol. 2020, 34, 101554. [CrossRef]

9. Li, Y.; Li, J.; Su, Q.; Liu, Y. Sinapine reduces non-alcoholic fatty liver disease in mice by modulating the composition of the gut microbiota. Food Funct. 2019, 10, 3637-3649. [CrossRef]

10. Nićiforović, N.; Abramovič, H. Sinapic Acid and Its Derivatives: Natural Sources and Bioactivity: Sinapic acid and its derivatives ... . Compr. Rev. Food Sci. Food Saf. 2014, 13, 34-51. [CrossRef]

11. Koski, A.; Pekkarinen, S.; Hopia, A.; Wähälä, K.; Heinonen, M. Processing of rapeseed oil: Effects on sinapic acid derivative content and oxidative stability. Eur. Food Res. Technol. 2003, 217, 110-114. [CrossRef]

12. Khattab, R.; Eskin, M.; Aliani, M.; Thiyam, U. Determination of Sinapic Acid Derivatives in Canola Extracts Using HighPerformance Liquid Chromatography. J. Am. Oil Chem. Soc. 2010, 87, 147-155. [CrossRef] [PubMed]

13. Augustyniak, A.; Bartosz, G.; Čipak, A.; Duburs, G.; Horáková, L.; Łuczaj, W.; Majekova, M.; Odysseos, A.D.; Rackova, L.; Skrzydlewska, E.; et al. Natural and synthetic antioxidants: An updated overview. Free Radic. Res. 2010, 44, 1216-1262. [CrossRef] [PubMed]

14. Chemat, F.; Abert Vian, M.; Ravi, H.K.; Khadhraoui, B.; Hilali, S.; Perino, S.; Fabiano Tixier, A.-S. Review of Alternative Solvents for Green Extraction of Food and Natural Products: Panorama, Principles, Applications and Prospects. Molecules 2019, $24,3007$. [CrossRef]

15. Alexovič, M.; Andruch, V.; Balogh, I.S.; Šandrejová, J. A single-valve sequential injection manifold (SV-SIA) for automation of air-assisted liquid-phase microextraction: Stopped flow spectrophotometric determination of chromium(VI). Anal. Methods 2013, 5, 2497-2502. [CrossRef]

16. da Costa Lopes, A.M.; Brenner, M.; Falé, P.; Roseiro, L.B.; Bogel-Łukasik, R. Extraction and Purification of Phenolic Compounds from Lignocellulosic Biomass Assisted by Ionic Liquid, Polymeric Resins, and Supercritical $\mathrm{CO}_{2}$. Acs Sustain. Chem. Eng. 2016, 4, 3357-3367. [CrossRef]

17. Flourat, A.L.; Willig, G.; Teixeira, A.R.S.; Allais, F. Frontiers I Eco-Friendly Extraction of Sinapine From Residues of Mustard Production I Sustainable Food Systems. Available online: https:/ / www.frontiersin.org/articles/10.3389/fsufs.2019.00012/full (accessed on 10 January 2020).

18. Reungoat, V.; Gaudin, M.; Flourat, A.L.; Isidore, E.; Mouterde, L.M.M.; Allais, F.; Ducatel, H.; Ioannou, I. Optimization of an ethanol/water-based sinapine extraction from mustard bran using Response Surface Methodology. Food Bioprod. Process. 2020, 122, 322-331. [CrossRef]

19. Shahidi, F.; Wanasundara, U.N.; Amarowicz, R. Natural antioxidants from low-pungency mustard flour. Food Res. Int. 1994, 27, 489-493. [CrossRef]

20. Dua, A.; Chander, S.; Agrawal, S.; Mahajan, R. Antioxidants from defatted Indian Mustard (Brassica Juncea) protect biomolecules against in vitro oxidation. Physiol. Mol. Biol. Plants 2014, 20, 539-543. [CrossRef]

21. Terpinc, P.; Čeh, B.; Ulrih, N.P.; Abramovič, H. Studies of the correlation between antioxidant properties and the total phenolic content of different oil cake extracts. Ind. Crop. Prod. 2012, 39, 210-217. [CrossRef]

22. Thiyam, U.; Stöckmann, H.; Felde, T.Z.; Schwarz, K. Antioxidative effect of the main sinapic acid derivatives from rapeseed and mustard oil by-products. Eur. J. Lipid Sci. Technol. 2006, 108, 239-248. [CrossRef]

23. Szydłowska-Czerniak, A.; Tułodziecka, A.; Karlovits, G.; Szłyk, E. Optimisation of ultrasound-assisted extraction of natural antioxidants from mustard seed cultivars. J. Sci. Food Agric. 2015, 95, 1445-1453. [CrossRef] [PubMed]

24. Mayengbam, S.; Aachary, A.; Thiyam-Holländer, U. Endogenous Phenolics in Hulls and Cotyledons of Mustard and Canola: A Comparative Study on Its Sinapates and Antioxidant Capacity. Antioxidants 2014, 3, 544-558. [CrossRef] [PubMed]

25. Fahmi, R. Antioxidant and Antibacterial Properties of Endogenous Phenolic Compounds from Commercial Mustard Products. Master's Thesis, University of Manitoba, Winnipeg, MB, Canada, 2016.

26. Librán Cuervas-Mons, C.M.; Mayor López, L.; García Castelló, E.M.; Vidal Brotons, D.J. Polyphenol extraction from grape wastes: Solvent and pH effect. Agricultural Sciences 2013, 4, 56-62. [CrossRef]

27. Roselló-Soto, E.; Martí-Quijal, F.J.; Cilla, A.; Munekata, P.E.S.; Lorenzo, J.M.; Remize, F.; Barba, F.J. Influence of Temperature, Solvent and $\mathrm{pH}$ on the Selective Extraction of Phenolic Compounds from Tiger Nuts by-Products: Triple-TOF-LC-MS-MS Characterization. Molecules 2019, 24, 797. [CrossRef] [PubMed]

28. Friedman, M.; Jürgens, H.S. Effect of pH on the Stability of Plant Phenolic Compounds. J. Agric. Food Chem. 2000, 48, 2101-2110. [CrossRef] [PubMed]

29. Chethan, S.; Malleshi, N.G. Finger millet polyphenols: Optimization of extraction and the effect of pH on their stability. Food Chem. 2007, 105, 862-870. [CrossRef] 
30. Thiyam-Holländer, U.; Eskin, N.A.M.; Matthäus, B. Canola and Rapeseed: Production, Processing, Food Quality, and Nutrition; CRC Press: Boca Raton, FL, USA, 2012; ISBN 978-1-4665-1388-4.

31. Durkee, A.B.; Thivierge, P.A. BOUND PHENOLIC ACIDS IN Brassica AND Sinapis OILSEEDS. J. Food Sci. 1975, 40, 820-822. [CrossRef]

32. Putnik, P.; Kovacevic, D.B.; Radojcin, M.; Dragovic-Uzelac, V. Influence of Acidity and Extraction Time on the Recovery of Flavonoids from Grape Skin Pomace Optimized by Response Surface Methodology. Chem. Biochem. Eng. Q. 2016, 30, 455-465. [CrossRef]

33. Cacace, J.E.; Mazza, G. Optimization of Extraction of Anthocyanins from Black Currants with Aqueous Ethanol. J. Food Sci. 2003, 68, 240-248. [CrossRef]

34. Bouras, M.; Chadni, M.; Barba, F.J.; Grimi, N.; Bals, O.; Vorobiev, E. Optimization of microwave-assisted extraction of polyphenols from Quercus bark. Ind. Crop. Prod. 2015, 77, 590-601. [CrossRef]

35. Peyrot, C.; Mention, M.M.; Fournier, R.; Brunissen, F.; Couvreur, J.; Balaguer, P.; Allais, F. Expeditious and sustainable twostep synthesis of sinapoyl-L-malate and analogues: Towards non-endocrine disruptive bio-based and water-soluble bioactive compounds. Green Chem. 2020, 22, 6510-6518. [CrossRef]

36. Rioux, B.; Peyrot, C.; Mention, M.M.; Brunissen, F.; Allais, F. Sustainable Synthesis of p-Hydroxycinnamic Diacids through Proline-Mediated Knoevenagel Condensation in Ethanol: An Access to Potent Phenolic UV Filters and Radical Scavengers. Antioxidants 2020, 9, 331. [CrossRef] [PubMed]

37. Martinović, N.; Poklar Ulrih, N.; Abramovič, H. Sinapic Acid and its Derivatives Increase Oxidative Stability in Different Model Lipid Systems. Eur. J. Lipid Sci. Technol. 2019, 121, 1800326. [CrossRef]

38. Gaspar, A.; Martins, M.; Silva, P.; Garrido, E.M.; Garrido, J.; Firuzi, O.; Miri, R.; Saso, L.; Borges, F. Dietary Phenolic Acids and Derivatives. Evaluation of the Antioxidant Activity of Sinapic Acid and Its Alkyl Esters. J. Agric. Food Chem. 2010, 58, 11273-11280. [CrossRef] [PubMed]

39. Brand-Williams, W.; Cuvelier, M.E.; Berset, C. Use of a free radical method to evaluate antioxidant activity. Lwt-Food Sci. Technol. 1995, 28, 25-30. [CrossRef]

40. R Core Team. R: A Language and Environment for Statistical Computing; R Foundation for Statistical Computing: Vienna, Austria, 2013; Volume 9. 